\begin{tabular}{rr} 
MEJRESS & $\begin{array}{r}\text { Middle Eastern Journal of Research in } \\
\text { Education and Social Sciences }\end{array}$ \\
\hline ISSN 2709-0140 (Print) and ISSN 2709-152X (Online) & Article 5 \\
Volume 3, Issue 1 & DOI: https://doi.org/ 10.47631/mejress.v3i1.445 \\
\hline
\end{tabular}

\title{
CONCEPTUAL KNOWLEDGE AND ITS IMPORTANCE IN TEACHING MATHEMATICS
}

\section{Yusuf Fakhraddin Hussein}

Eötvös Loránd University, Budapest, Hungary

\section{ARTICLE INFO \\ Received: 13 December 2021 \\ Revised: 28 February 2022 \\ Accepted: 02 March 2022}

\section{Keywords:}

Conceptual Understanding, Procedural Understanding,

Teacher Perspectives,

Conceptual Teaching

Corresponding Author:

Yusuf Fakhraddin Hussein

Email: Yusuf.hussein@ppk.elte.hu Copyright $@ 2022$ by Author(s)

This work is licensed under the Creative Commons Attribution International License (CC BY 4.0). http://creativecommons.org/licenses/ by/4.0/
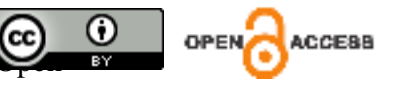

\begin{abstract}
Purpose: This study highlights the importance of teaching conceptual knowledge alongside procedural knowledge in mathematics. It examines the effects of a lack of conceptual knowledge on students' responses to mathematics teaching from the perspectives of researchers and educators.

Approach/Methodology/Design: This study draws on interviews with 30 secondary school mathematics teachers from Erbil in the Kurdistan region of Iraq on conceptual knowledge in mathematics. The study focuses on three main areas: mathematics teachers' perspectives on teaching conceptual knowledge, the conditions needed to teach conceptual knowledge, and the obstacles that they face in teaching conceptual knowledge.

Findings: A thematic analysis of the interviews revealed that mathematics teachers believed that conceptual knowledge is as important as procedural knowledge. In addition, they believed that achieving a balance between conceptual and procedural understanding and emphasizing the connections between them are necessary for understanding real mathematics.

Practical Implications: Many mathematics teachers tend to use traditional teaching methods that focus on procedure and neglect conceptual mathematics. The results of this study would offer insights into the difficulties associated with mathematics teaching. Moreover, it would have practical implications for curriculum planning, emphasizing the balance of both conceptual and procedural knowledge.

Originality/value: The study focuses on mathematics teachers' perspectives on teaching mathematics conceptually, the conditions needed to teach conceptually, and the obstacles that they face in teaching mathematics conceptually.
\end{abstract}

\section{INTRODUCTION}

Over the past few decades, mathematics researchers and educators have highlighted the need to teach conceptual mathematics (Baroody \& Lai, 2007; Andrew, 2019; Crooks \& Alibali, 2014; Bransford et al., 2000; Clarke-Midura \& Dede, 2010). Learners must have conceptual knowledge to successfully understand mathematical ideas and transfer their knowledge to new situations (National Council of Teachers of Mathematics, 2000). Once students gain conceptual understanding, they can assess which procedure is suitable for a specific mathematical problem (Brownell, 1945; Schneider \& Stern, 2010). Therefore, teaching mathematics conceptually is central to students' better understanding of mathematics; indeed, 
researchers and educators have increasingly shifted from procedural knowledge to conceptual knowledge (Crooks \& Alibali, 2014).

However, many mathematics teachers tend to use traditional teaching methods that focus on procedure and neglect conceptual mathematics. A study on the teaching of conceptual knowledge (Zaini, 2005) showed that trainee teachers relied on algorithms, formulas, and rules to explain problems rather than an evidence-based conceptual understanding. Similarly, primary school mathematics teachers in Saudi Arabia (Khashan et al., 2014) relied more on procedural knowledge than conceptual knowledge. As a result, students learn rules that are inadequate for solving mathematics problems that require deep understanding (i.e., nontraditional problems). For example, secondary school students in the Kurdistan region of Iraq had difficulty defining the concept of a function (Hussein \& Csaba, 2021). The study revealed many problems: students tended to conflate concept image and concept definition, were only able to provide a partial definition of functions and had difficulty recognizing different representations of functions and conversions. Therefore, the present study examines mathematics' teachers' perspectives on the necessity of teaching mathematics conceptually and the obstacles that they face in this endeavor. To this end, semi-structured interviews were conducted with 30 mathematics teachers in Erbil, Iraq. Then, the interviews were analyzed and interpreted in relation to the research questions.

The present study investigates the importance of conceptual knowledge in mathematics teaching from the perspectives of mathematics teachers. The aim is to disseminate results and contribute to improving the teaching of mathematics. The study is guided by the following research questions:

1. What are mathematics teachers' levels of familiarity with conceptual understanding?

2. What are mathematics teachers' perspectives on teaching mathematics conceptually?

3. What do mathematics teachers need to teach conceptually?

4. What are the obstacles that mathematics teachers face when teaching mathematics conceptually?

\section{LITERATURE REVIEW}

\section{Conceptual knowledge}

There are various definitions of conceptual knowledge in mathematics studies. However, these are sometimes implicitly rather than explicitly referenced. Despite these variations, mathematics education researchers tend to define conceptual knowledge as rich knowledge about relationships and connections, similar to a web of knowledge (Hiebert \& Lefevre, 1986; National Research Council \& the NCTM, 2000). In other words, conceptual understanding means understanding how all pieces of information are linked together in a network (Rittle-Johnson \& Schneider, 2015; Baroody et al., 2007). It can be defined as an "understanding of the underlying structure of mathematics the relationships and interconnections of ideas that explain and give meaning to mathematical procedures" (Faulkenberry, 2003, p. 13). In terms of its implications for teaching, conceptual knowledge means the "comprehension of mathematical concepts, operations, and relations" (Kilpatrick, 2001, p. 5). According to Reys et al. (1995, p. 21), conceptual knowledge requires "the learner to be active in thinking about relationships and making connections, along with making adjustments to accommodate the new learning with previous mental structures." 
Therefore, mathematical researchers define conceptual knowledge as a relation to the connection and linkage of ideas.

In some mathematics education studies, conceptual knowledge has been defined in terms of principles. For instance, according to Baroody et al. (2007, p. 123), "conceptual knowledge is knowledge about facts (generalizations) and principles." In the classroom, "having conceptual knowledge involves the student understanding the meaning and underlying principles of mathematical concepts" (Frederick \& Kirsch, 2011, p. 94). Accordingly, conceptual knowledge is sometimes called conceptual understanding or principled knowledge (Kilpatrick et al., 2001).

Mathematics education researchers have defined this type of knowledge without reference to it being "conceptual." For example, the National Research Council (2001, p. 118) referred to it as "an integrated and functional grasp of mathematical ideas." Robinson and Dube (2009a, p. 193) explained it as "the understanding of the underlying structures of mathematics," while Lampert (2001) and Ball et al. (2001) understood it as the knowledge that stimulates the growth of mathematical algorithms. Thus, the meaning of conceptual knowledge has expanded to include the grasp of ideas, mathematical structures, and stimulation of algorithms. As shown above, there are various definitions of conceptual knowledge. However, the most common - and the one used in this article-is the understanding of relationships and connections between ideas, symbols, and numbers and of fundamental procedures as a web of knowledge (Bolden \& Newton, 2008; Dixon \& Moore, 1996).

\section{Procedural knowledge}

There are two aspects to the definition of procedural knowledge. The first is knowledge of the formal language, which is called symbolic representation, and the second is knowledge of the rules used to complete a mathematical task. Rittle-Johnson and Schneider $(2015$, p. 4$)$ defined procedure knowledge as a "series of steps, or actions, done to accomplish a goal." Furthermore, it is "knowledge of the steps required to attain various goals" (Canobi, 2009, p. 176). According to Engelbrecht et al. (2017), "a procedural approach includes algebraic, numerical calculations, employing rules, algorithms, formulae and symbols" (574). Procedural knowledge has also been defined as the "mastery of computational skills and knowledge of procedures for identifying mathematical components, algorithms, and definitions" (Faulkenberry, 2003, p. 13). Finally, Hiebert and Carpenter (1992) understood procedural knowledge as a series of actions that, if executed correctly, will lead to the right answer. Thus, all these definitions refer to the idea that knowledge relates to sequences of procedures that can be used in mathematical problem-solving.

\section{Relationship between conceptual and procedural knowledge}

Mathematics educators believe that both conceptual and procedural knowledge are essential (Hurrell, 2021). For instance, Kilpatrick et al. (2001) stated that procedural knowledge is primarily needed to support conceptual knowledge. Thus, connecting these two types of knowledge is key to developing mathematical understanding (Hiebert \& Lefevre, 1986). Similarly, simultaneously developing these two types of knowledge has a positive effect on mathematical competence (Rittle-Johnson \& Schneider, 2015). Accordingly, conceptual understanding is supported by algorithms and provides building blocks that can be used to clarify concepts. Conversely, students can develop algorithms through conceptual understanding (Aydin, 2018). Thus, conceptual and procedural knowledge are often 
mentioned together because they are believed to have a coherent relationship between them (Rittle-Johnson \& Schneider, 2015).

However, conceptual knowledge is distinct from procedural knowledge in several respects. Conceptual knowledge has strong relationships with different parts of knowledge, whereas procedural knowledge is a conventional sequence of steps (Hiebert \& Lefevre, 1986). Moreover, procedural understanding only concerns algorithms and facts, while conceptual knowledge confirms students' ability to link mathematics across disciplines and critical thinking with the communication of critical components of mathematics (Hiebert \& Lefevre, 1986; Linn, 1994).

In summary, students must be given opportunities to connect these two types of knowledge (Ministry of Education, 2001) because they must have a variety of perspectives on mathematics in problem-solving and build connections between them to have better performance in mathematics (National Council of Teachers of Mathematics, 1989).

\section{Importance of conceptual knowledge in mathematics teaching}

There is a positive correlation between the conceptual understanding of mathematics and academic achievement. For example, a study by Zakaria et al. (2010) found a significant relationship between conceptual knowledge and mathematics achievement. Investigating conceptual knowledge helps learners gain procedural knowledge. In Lauritzen's study (2012), students who scored highly on conceptual tasks also scored highly on procedural tasks. Therefore, "the results support the genetic view that procedural knowledge is a necessary but not sufficient condition for conceptual knowledge" (Lauritzen, 2012, p. 13). Furthermore, a low level of conceptual knowledge was recorded among first-year students in the mathematics department at the College of Education (Saeed, 2016). When students are asked to solve a mathematical problem, they can use processes to find the correct solution despite lacking an understanding of their "how" and "why" (Barr et al., 2003).

However, many studies have indicated that a lack of conceptual knowledge leads to a variety of challenges. For example, students have difficulty with algebraic concepts such as algebraic expressions due to a lack of conceptual knowledge (Tekin-Sitrava, 2017). In Rittle-Johnson and Alibali's (1999) study, equivalent tasks were provided to students, and they were asked to decide which one was correct and which one had no meaning. The study found that $86 \%$ of participants failed to solve the problems because they lacked basic arithmetic skills. In addition, a study by Carlson (1998) found that university students were unable to solve an unconventional problem on the development of the concept of a function. Specific problems have been identified in the research. For example, in calculus, derivation was found to be particularly difficult for most undergraduate students to understand (Saha et al., 2010). This difficulty is believed to result from students' lack of conceptual understanding of the concept (Willcox \& Bounova, 2004; Saha et al., 2010). Therefore, a lack of conceptual knowledge is a reason for students' weak performance in mathematics (Knuth et al., 2005).

\section{METHODOLOGY AND PROCEDURES}

\section{Study population}

A study population is defined as "the set or group of all the units on which the findings of the research are to be applied" (Shukla, 2020, p. 3). The population for this study is secondary 
school mathematics teachers in Erbil in the Kurdistan region of Iraq. This area was chosen for two main reasons. Firstly, according to the researcher's experience, students have difficulty with mathematics. Secondly, the researcher is originally from Erbil, which made it easier to contact teachers and persuade them to participate in this study.

Table 1: Participants' Experience with Mathematics Teaching

\begin{tabular}{|l|c|c|c|c|}
\hline Years of experience & $1-5$ & $6-10$ & $11-15$ & 16 and over \\
\hline Number of participants & 4 & 6 & 13 & 7 \\
\hline
\end{tabular}

\section{Participants}

To investigate the research questions, individual semi-structured interviews were conducted with secondary school mathematics teachers in Kurdish (Bryman, 2004). The researcher made a blog that contained all details about the current study: title, research aim, definitions, and a call for voluntary participation. Then, mathematics teachers in Erbil were contacted via email, phone, and social media. As a result, 30 secondary school mathematics teachers were recruited for the sample. The participants were chosen based on a set of basic criteria; they had to cover a range of geographical locations in the city and have different years of teaching experience. Most participants were male; in total, there were 19 men and 11 women. All of them have a Batchelor certificate in mathematics. Four participants had up to five years of teaching experience and the rest had over six years of teaching experience (see Table 1).

\section{Instruments}

A qualitative research approach is very useful for exploring the human aspects of a specific practice or type of education (Stojanov \& Dobrilovic, 2013). It depicts real-life situations, and its interpretation of phenomena is based on information mainly gained from participants (Stojanov \& Dobrilovic, 2013). Thus, qualitative research can provide a detailed and in-depth view of situations and circumstances.

Since the development of qualitative methodologies, the qualitative interview has become an essential tool in mathematics education research (Zazkis \& Hazzan, 1998). A variety of research approaches provides the researcher with different ways to reveal new problems and expand ways to solve problems in education (Jacob, 1998). In the present study, in-depth and open-ended interviews were utilized. Specifically, open-ended questions were used to gain detailed information about perceptions, feelings, and experiences (Patton, 2001), while interviews were used to generate rich detail, which is important for understanding mathematics teachers' perspectives on conceptual knowledge (Stojanov \& Dobrilovic, 2013).

Interview questions were chosen based on the main research questions for the study. Then, mathematics education scholars in Erbil were asked open-ended questions. Finally, questions were constructed and prepared as appropriate to fit participants (see Appendix A). The accuracy and suitability of the data collection instrument was ensured through a pilot study. The purpose of the pilot study was to uncover and track any weaknesses before conducting it with an entire community (Walsh, 2001). Two mathematics teachers in the Kurdistan region of Iraq were interviewed to ensure that the interview questions were appropriate and clear. The pilot study showed that the interview questions were clear and that the time allocated for 
each interview (30 minutes) was enough. Nevertheless, a few amendments were made to the questions.

The interview stage began on January 1, 2021, and ended on March 20, 2021. The interviews were scheduled outside of the classroom, and each interview took around 30 minutes. To understand secondary school mathematics teachers' perceptions of conceptual and procedural knowledge in greater depth, the interviews were transcribed and coded.

\section{Research ethics}

In this study, the principles of research ethics were carefully considered. The study's ELTE PPK Research Ethics Committee license number is 2020/209. All participants signed an electronic consent form. Furthermore, all participants were asked whether they were willing to have their voices recorded; only 18 out of 30 interviewees agreed. Pseudonyms were used to protect their privacy and confidentiality.

\section{Evidence of validity and reliability}

To determine the validity of the instrument, a group of experts, which consisted of the researcher's supervisors and mathematics education professors, was invited to review it. After the panel review, comments were collected and considered by the researcher. The panel made a few suggestions for revision; otherwise, the other items in the instrument were found to be commensurate with the research questions for this study.

\section{The education system in Kurdistan}

In the state school system in Kurdistan, students attend school for four and a half hours per day, six days per week. There are two semesters in an academic year: the first semester lasts from September to January, and the second semester lasts from February to June. There are five mathematics sessions in a week, and each session lasts 40 minutes. The formal method of teaching mathematics in Kurdistan combines conceptual and procedural teaching. However, for a variety of reasons that are explained in the following sections, mathematics teachers generally tend towards procedural teaching.

\section{Research focus and design}

Semi-structured interviews were conducted for this study. The interview questions were formulated according to three aims. The first was to reveal mathematics teachers' familiarity with conceptual knowledge and teaching conceptually - in other words, their understanding of conceptual knowledge and the differences between conceptual and procedural teaching. The second was to reveal the importance of teaching mathematics conceptually from the perspectives of mathematics teachers - in other words, why teaching mathematics conceptually is important and the teaching methods applied by teachers in the classroom. The final perspective was to identify obstacles that mathematics teachers face in teaching conceptual knowledge and how they can be managed (see Table 2).

\section{RESULTS AND DISCUSSION}

After the data collection stage, the researcher transcribed all audio recordings and read them several times for accuracy. For participants who did not consent to be recorded, the interviewer took notes during the interview. The interviews were transcribed on the same day that they took place (ideally directly after each interview) to reduce recall bias. Then, the 
transcribed interviews were interpreted. In a process called condensation, the text was shortened while maintaining its core meaning (Erlingsson \& Brysiewicz, 2017). To facilitate the analytical process, coding techniques were used to identify and record underlying ideas in the data. The coding process can be used to clarify, structure, and develop deeper meanings from the interview conversations. According to Erlingsson and Brysiewicz (2017, p. 2), "a code can be thought of as a label; a name that most exactly describes what this particular condensed meaning unit is about, usually one or two words long." Deductive coding was used in the present study to focus on the research questions. Also known as concept-driven coding, the process of deductive coding begins with predefined codes, which are then applied to the new qualitative data (Medelyan, 2021). The next step was to categorize and group the codes to make sense of the data. Codes that are related in content or context can be grouped to make a category (Erlingsson \& Brysiewicz, 2017). Next, three main themes were identified based on the aforementioned three main perspectives (Erlingsson \& Brysiewicz, 2017). Then, different ideas and themes are related to each other to answer the main research questions (Rubin \& Rubin, 1995). Finally, the study was concluded by formulating advice and recommendations for education directors, supervisors, school administrators, and mathematics teachers (see Table 2).

Table 2: Data Analysis Classifications

\begin{tabular}{|c|c|c|}
\hline \multirow{3}{*}{$\begin{array}{l}\text { Familiarity } \\
\quad \text { with } \\
\text { conceptual } \\
\text { knowledge }\end{array}$} & \multirow{2}{*}{$\begin{array}{l}\text { Meaning of } \\
\text { conceptual } \\
\text { knowledge }\end{array}$} & $\begin{array}{c}\text { Familiarity without any explanation: } \\
\text { Around } 20 \% \text { of participants (six interviewees) were familiar } \\
\text { with the term "conceptual knowledge." }\end{array}$ \\
\hline & & $\begin{array}{c}\text { Familiarity with researcher's explanation: } \\
\text { Seventy percent of participants ( } 21 \text { interviewees) recognized } \\
\text { the meaning of conceptual knowledge after the researcher's } \\
\text { explanation. }\end{array}$ \\
\hline & $\begin{array}{l}\text { Differences } \\
\text { between } \\
\text { conceptual and } \\
\text { procedural } \\
\text { teaching }\end{array}$ & $\begin{array}{l}\text { Teaching conceptually, teaching procedurally: } \\
\text { Overall, } 63.3 \% \text { of participants ( } 19 \text { interviewees) named clear } \\
\text { differences between the two teaching methods. }\end{array}$ \\
\hline \multirow{4}{*}{$\begin{array}{l}\text { Perspectives } \\
\text { on teaching } \\
\text { mathematics } \\
\text { conceptually }\end{array}$} & \multirow{2}{*}{$\begin{array}{l}\text { Perspectives on } \\
\text { the importance of } \\
\text { teaching } \\
\text { mathematics } \\
\text { conceptually }\end{array}$} & $\begin{array}{l}\text { Teaching conceptually is not important: } \\
\text { Overall, } 6.6 \% \text { of participants (two interviewees) believed that } \\
\text { teaching mathematics conceptually was not important. }\end{array}$ \\
\hline & & $\begin{array}{l}\text { Teaching conceptually is important: } \\
\text { Overall, } 93.3 \% \text { of participants ( } 28 \text { interviewees) believed that } \\
\text { teaching mathematics conceptually was important. }\end{array}$ \\
\hline & \multirow{2}{*}{$\begin{array}{l}\text { Teaching } \\
\text { methods used by } \\
\text { teachers in the } \\
\text { classroom }\end{array}$} & $\begin{array}{c}\text { Teaching procedurally: } \\
\text { Overall, } 73.3 \% \text { of participants ( } 22 \text { interviewees) only taught } \\
\text { mathematics procedurally. }\end{array}$ \\
\hline & & $\begin{array}{c}\text { Teaching conceptually and procedurally: } \\
\text { Only } 26.6 \% \text { of participants (eight interviewees) combined } \\
\text { conceptual and procedural teaching. }\end{array}$ \\
\hline \multicolumn{2}{|c|}{$\begin{array}{l}\text { Factors needed for conceptual } \\
\text { teaching }\end{array}$} & $\begin{array}{ll}- & \text { More time } \\
\text { - } & \text { Training course for teachers } \\
\text { - } & \text { Reducing the amount of students' curriculum } \\
\text { - } & \text { Teaching method in Kurdistan }\end{array}$ \\
\hline
\end{tabular}




\begin{tabular}{|c|c|c|}
\hline \multirow{2}{*}{$\begin{array}{l}\text { Obstacles to } \\
\text { teaching } \\
\text { conceptual } \\
\text { knowledge }\end{array}$} & Obstacles & $\begin{array}{ll}\text { - } & \text { Insufficient time } \\
\text { - } & \text { Insufficient knowledge among teachers } \\
\text { - } & \text { Pressure by school administrators and supervisors to } \\
\text { complete the curriculum during the academic year } \\
\text { - } & \text { Some mathematics teachers believed that conceptual } \\
\text { teaching complicates mathematics for students } \\
\text { - } \quad \begin{array}{l}\text { Many students only want to pass their mathematics } \\
\text { course rather than develop a deep understanding of the } \\
\text { topic }\end{array}\end{array}$ \\
\hline & $\begin{array}{l}\text { Potential } \\
\text { solutions }\end{array}$ & $\begin{array}{l}\text { - Increase duration and weekly frequency of } \\
\text { mathematics class } \\
\text { - } \quad \text { Hold open training course for mathematics teachers } \\
\text { Encourage school administrators and supervisors to } \\
\text { not only focus on completing the curriculum but also } \\
\text { on achieving better understanding } \\
\text { - } \quad \text { Foster mathematics communities to exchange } \\
\text { information } \\
\text { Make contentment for mathematics teachers that } \\
\text { teaching mathematics conceptually is not a waste of } \\
\text { time and does not make mathematics more } \\
\text { complicated for students, by academic debate }\end{array}$ \\
\hline
\end{tabular}

\section{Results}

Most participants $(80 \%)$ were not familiar with the term "conceptual knowledge." For example, one participant said, "I do not know exactly what you mean by "conceptual knowledge." However, 70\% of participants had some understanding of the term when the researcher offered some explanation. One participant said, "After your clarification, now I know exactly what you mean by teaching mathematics conceptually and conceptual knowledge." In addition, $63.3 \%$ of participants were able to differentiate between teaching conceptually and procedurally.

While some interviewees were familiar with teaching mathematics conceptually, they did not apply it to their classroom teaching. Most participants $(93.3 \%)$ believed that teaching mathematics conceptually was important and necessary for students to develop a better understanding of mathematics. One interviewee stated that, "if we want to teach mathematics better in the classroom, we have to start by teaching conceptually." Interviewees did not doubt that imparting conceptual knowledge in addition to procedural knowledge would increase students' mathematics performance. When the researcher asked participants why they did not use this practice in the classroom, many answered that they did not have enough time to teach mathematics in this manner. Moreover, two participants believed that teaching mathematics conceptually would make the subject more complicated for students.

Interviewees identified several prerequisites for teaching conceptual knowledge in mathematics. Most participants $(73.3 \%)$ believed that teaching conceptually was timeconsuming and would result in them not being able to complete the curriculum. One participant said, "I do not want to waste my time because I have to finish the curriculum until the end of the academic year." Thus, they proposed that a reduction in the curriculum content would make teaching conceptually more feasible. One interviewee said, "If we need to teach conceptually, curtailing the curriculum will be needed." Another stated, "Without reducing the curriculum, it is impossible to apply conceptual teaching in the classroom." Professional development was also a necessary factor for mathematics teachers to familiarize themselves 
with teaching conceptually, as they must have up-to-date knowledge on teaching methods. One participant said, "We need training courses if we want to teach mathematics conceptually because there are a lot of questions that should be discussed." Finally, the same teaching methods should be used by mathematics teachers. Participants believed that the education directors, heads of school, and school supervisors should require mathematics to be taught conceptually. One interviewee said, "Of course, if there is no rule that forces me to teach conceptually, I will use the easiest and the quickest method of teaching." Another asked, "Why do I have to teach conceptually, which consumes more time and energy compared to teaching procedurally?"

In addition, participants mentioned obstacles in teaching conceptually, mainly a lack of time. The interviewees believed that they had a very limited time to teach mathematics and thus could not teach it at a deep level. One participant said, "Teaching conceptually needs more explanation. Therefore, it consumes more time. According to our school's rule, we do not have enough time for that teaching." In addition, mathematics teachers were not entirely familiar with teaching conceptually. Another obstacle is that both school administrators and supervisors are very strict about completing the curriculum during the academic year. This leads many teachers to teach mathematics procedurally rather than conceptually. One respondent said, "Completing the curriculum and students' grades are the core aspects for school administrators and mathematics inspectors, so I should focus on these." Some mathematics educators believed that teaching conceptually was not necessary because it complicated mathematics for students. One participant asked, "Why do I have to make mathematics more complicated for students by teaching conceptually?" Another respondent said, "When I try to explain mathematics to students too much, they become confused." Finally, many students only aim to pass their mathematics course; they do not want to understand mathematics too deeply. Instead, they focus on procedures for solving mathematics problems to pass the exam.

\section{Discussion}

Over the past few decades, there has been an increase in the number of studies on conceptual understanding. They emphasize students' understanding of mathematical concepts and their ability to solve mathematical problems (Star, 2005). Likewise, participants in the present study believed that imparting both conceptual and procedural knowledge was necessary for students to better understand mathematics. One participant noted, "It will be very helpful if all mathematics teachers teach conceptually and procedurally." This comment refers to the many useful aspects of conceptual knowledge. Firstly, conceptual knowledge can help students to evaluate the most suitable procedure for a specific mathematical problem (Carr et al., 1994; Garofalo \& Lester, 1985). Secondly, it provides more flexibility in problemsolving, as students with adequate conceptual knowledge can generalize procedures to a new problem (Baroody et al., 2007; Rittle-Johnson et al., 2001; Blöte, 2000). Thirdly, it can be used to check the truth of a solution after the problem has been solved (Garofalo \& Lester, 1985). Fourth, conceptual knowledge can give students greater confidence when they are confronted with different mathematical problems (Korn, 2014; Carr et al., 1994; Schneider \& Stern, 2010; Garofalo \& Lester, 1985). Finally, with structured and organized knowledge, students can relate information beyond isolated facts or automatic procedures (Bransford et al., 2000). All these points are made to encourage mathematics researchers and educators to focus on conceptual knowledge.

The present study shows that the participants had some background in teaching conceptually. However, they did not try to teach conceptually in their classrooms. Only $20 \%$ of 
interviewees were able to define conceptual knowledge without any explanation from the researcher. When prompted, they remembered what they had learned about conceptual knowledge. This means that mathematics teachers in Kurdistan generally focus on teaching procedurally in their classrooms despite having some background in conceptual teaching.

Regarding teaching methods, only eight participants stated that they combined conceptual and procedural teaching. One of them said, "My students are very happy because I explain mathematics to them very clearly and deeply." It seems that these students appreciate this teaching method. Another interviewee said, "It is true that I am a bit more tired than usual with teaching conceptually beside procedurally, but my students are comfortable because they can understand real mathematics." The other participants used the procedural approach to mathematics teaching. Three participants believed that teaching mathematics in depth and explaining it in terms of relationships made mathematics too complicated for students; as a result, the students would dislike mathematics class even more. One interviewee said, "I explain mathematics rules to the students, and I teach them how to use those rules in solving mathematics problems. Why would I need to make the mathematics class more complicated by giving them deeper explanations?" Another stated, "We do not have problems with teaching procedurally, and my students' grades are reasonable." In addition, seven interviewees believed that teaching conceptually was only necessary for some subjects in mathematics. One said, "Some of the subjects in mathematics need conceptual teaching, but some others do not need it. For example, some very pure mathematics subjects can only be explained procedurally." Six of the interviewees believed that teaching conceptually not only depended on teaching methods but also the curriculum, school system, and school environment. One participant stated, "The four columns - the teacher, students, school system, and curriculum - are necessary to support the conceptual teaching of mathematics."

In terms of solutions, interviewees mentioned that increasing the number of mathematics classes per week and class duration were needed to apply conceptual teaching. Interviewees believed that increasing the duration of mathematics class from 40 minutes to 70 minutes and the number of mathematics classes from five to six classes per week should be considered. In addition, training sessions that focus on up-to-date teaching methods should be offered to mathematics teachers. One participant stated, "Mathematics teachers need to participate in training courses to develop their knowledge about teaching conceptual knowledge." Moreover, it is crucial for mathematics teachers to have their own communities in which to exchange knowledge and discuss teaching problems with mathematics experts. Furthermore, school administrators and supervisors should not only focus on completing the curriculum but also on teaching quality and ensuring students' understanding. Through academic debate, mathematics teachers must be persuaded that teaching mathematics conceptually is neither a waste of time nor makes mathematics more complicated for students. Finally, both students and teachers should be encouraged to focus on conceptual understanding alongside procedural understanding by formulating exam questions that require students to have conceptual knowledge to correctly answer.

Despite a noticeable shift in focus towards conceptual knowledge among researchers and educators, participants in this study mentioned many obstacles to teaching mathematics conceptually. First, conceptual knowledge can be implicit or explicit, which means that it might be not verbalizable (Goldin-Meadow et al., 1993). Only around half of participants could differentiate between teaching mathematics conceptually and procedurally. Some of them confused the two teaching approaches, while others provided ambiguous answers (e.g., "By teaching conceptually, the mathematics teacher will connect the subject with our daily 
lives, while, by teaching procedurally, the mathematics teacher only focuses on pure mathematics."). Seven interviewees did not want to provide any explanation and said that they did not remember in the moment. The participants also believed that, for some advanced mathematics subjects, the topic cannot be explained in depth; instead, it can only be explained procedurally. This is consistent with previous studies that indicated that conceptual and procedural knowledge cannot be easily differentiated because they are so deeply intertwined (Long, 2005; Baroody \& Lai, 2007; Crooks \& Alibali, 2014; Star, 2005).

Another obstacle to conceptual teaching is pressure from supervisors and school administrators to complete the curriculum and increase students' pass rate. Thus, the focus is on quantity rather than quality in students' understanding of mathematics. According to Zakaria et al. (2010), school administrators encourage mathematics teachers to concentrate on student achievement in exams and on completing the curriculum regardless of students' satisfaction with mathematics courses or depth of understanding. Therefore, most mathematics assessments traditionally depend on students' ability to procedurally manipulate knowledge, and assessment tools focus on procedural knowledge rather than both conceptual and procedural knowledge (De Zeeuw et al., 2013).

Insufficient understanding of the nature and structure of mathematical knowledge is another reason why teachers focus on procedural knowledge rather than conceptual knowledge (Hallett et al., 2012; Lin et al., 2013). In this study, interviewees believed that mathematics teachers did not have enough knowledge to teach all mathematics subjects conceptually. Therefore, they proposed training courses for mathematics teachers and the development of communities for academic discussion with support from mathematics experts.

Procedural knowledge has become standard knowledge for solving mathematics problems. For example, students are graded on exams based on the number of correct answers (RittleJohnson \& Siegler, 1998). This is consistent with the results of the present study, as some participants believed that teaching conceptually was not necessary because assessment tools are based on procedural knowledge. One of the participants said, "I tell my students mathematics rules and how to use them for problem solving. My students' grades are reasonable, and we do not have a problem with procedural knowledge."

Finally, some mathematics teachers believe that prioritizing conceptual knowledge is timeconsuming compared to procedural knowledge because this requires more explanation and a deeper understanding of the topic (Baroody \& Lai, 2007; Crooks \& Alibali, 2014). Participants in this study confirmed that teaching conceptually is time-consuming, which is difficult to manage. For example, one interviewee said, "It is not easy to teach mathematics conceptually in the classroom within a 40-minute class period." However, according to Andrew (2019), it is time-consuming not to prioritize procedural knowledge over conceptual knowledge in mathematics teaching because students spend significant amounts of time not understanding what they are working on; as a result, mathematics courses become unpleasant and boring. Andrew provided two main reasons for this. Firstly, a better understanding of mathematics reduces the time that students spend being confused. If students do not understand key concepts, they struggle to remember rules and procedures. Secondly, students with a good understanding of mathematics require less practice. If mathematics teachers apply a conceptual approach to teaching first and a procedural approach later, students do not require much practice to solve problems (Andrew, 2019).

In summary, most participants in the present study believed that teaching both conceptual and procedural knowledge was necessary for students to better understand mathematics. 
However, they preferred procedural teaching for several reasons, the main ones being the pressure that they are under to complete the curriculum in an academic year and ensure a high pass rate among students and the fact that they regard teaching procedural knowledge as being easier.

\section{CONCLUSION AND SUGGESTION}

Mathematics does not consist of a collection of isolated facts and algorithms; rather, it is a web of interconnected elements (Nik Pa, 2003). Likewise, there is a relationship between conceptual knowledge and procedural knowledge; gains in conceptual knowledge lead to increases in procedural knowledge (Rittle-Johnson et al., 2001; Lauritzen, 2012; RittleJohnson \& Schneider, 2015). Therefore, this study investigates the importance of conceptual teaching in addition to procedural teaching in mathematics from the perspectives of mathematics teachers in Kurdistan, to disseminate the results. The study focuses on mathematics teachers' perspectives on teaching mathematics conceptually, the conditions needed to teach conceptually, and the obstacles that they face in teaching mathematics conceptually.

The results revealed that most participants believed that teaching conceptual knowledge alongside procedural knowledge was crucial for students to have a better understanding of mathematics (Nahdi \& Jatisunda, 2020). This finding is consistent with previous studies. For example, the National Governors Association Center for Best Practices and Council of Chief State School Officers (2010) stated that, by focusing on conceptual knowledge in mathematics teaching, students would gain a deeper understanding of mathematics and that information would be retained for a longer period of time. To improve learning quality and student achievement, it is vital to help students to understand mathematics conceptually. Once students gain conceptual knowledge, they can assess the suitable procedure to use in a specific mathematical problem (Brownell, 1945; Schneider \& Stern, 2010).

However, only a few participants in the present study combined procedural and conceptual teaching in their classes. Participants saw teaching conceptually as time-consuming because it requires more explanation and a deeper understanding of the topic. Others believe that teaching conceptually was not necessary because it made mathematics more complicated for students. These reasons discouraged mathematics teachers from teaching conceptually. Based on the results of the present study, some recommendations were formulated for mathematics teachers, school administrators, supervisors, education directors, and the ministry of education, Kurdistan of Iraq. First, it is recommended that mathematics teaching focuses on both conceptual knowledge and procedural knowledge since conceptual teaching is key to a better understanding of mathematics among students. Furthermore, there should be a focus on teaching quality and students' understanding of mathematics.

Secondly, through academic debate, the education directors, school administrators, and supervisors should persuade mathematics teachers that teaching mathematics conceptually is not a waste of time and does not make mathematics more complicated for students. Increasing the frequency of mathematics classes from five to six classes per week is recommended to allow teachers to have more time to explain mathematics. Finally, exam questions should be formulated in a way that requires students to have a conceptual understanding of the topic; this would motivate both students and teachers to focus on conceptual understanding alongside procedural understanding. 


\section{CONFLICT OF INTEREST}

There are no conflicts of interest with this paper.

\section{FUNDING}

The costs of conducting the study and publishing this article are of the authors.

\section{REFERENCES}

Aydın, U. (2018). Conceptual and procedural angle knowledge: do gender and grade level make a difference?, International Journal for Mathematics Teaching And Learning, 19(1), 22-46.

Aydin, Y. (2014). The effects of problem based approach on student's conceptual understanding in a university mathematics classroom. Procedia-Social and Behavioral Sciences, 152, 704-707. https://doi.org/10.1016/j.sbspro.2014.09.307

Bisanz, J., Watchorn, R., Piatt, C. \& Sherman, J. (2009). On "understanding" children's developing use of inversion. Mathematical Thinking and Learning, 11(1-2), 10-24. https://doi.org/10.1080/10986060802583907

Baroody, A. J. \& Lai, M. (2007). Preschoolers' Understanding of the Addition-Subtraction Inverse Principle: A Taiwanese Sample. Mathematical Thinking and Learning, 9(2), 131-171. https://doi.org/10.1080/10986060709336813

Baroody, A., Feil, Y. \& Johnson, A. (2007). An alternative reconceptualization of procedural and conceptual knowledge. Journal for research in mathematics education, 115-131. https://doi.org/10.2307/30034952

Ball, L., Lubienski, T. \& Mewborn, S. (2001). Research on teaching mathematics: The unsolved problem of teachers' mathematical knowledge. Handbook of research on teaching, 4, 433-456.

Bransford, J., Brown, A. \& Cocking, R. (2000). How people learn. $11^{\text {th }}$ edn. Washington, DC: National academy press.

Blöte, A., Klein, A. \& Beishuizen, M. (2000). Mental computation and conceptual understanding. Learning and Instruction, 10(3), 221-247. https://doi.org/10.1016/S0959-4752(99)00028-6

Brownell, W. (1945). When is arithmetic meaningful?. The Journal of Educational Research, 38(7), 481-498.https://doi.org/10.1080/00220671.1945.10881369

Bryman, A. (2004). Social Research Methods. 2nd edn. Oxford: Oxford University Press.

Crooks, N. \& Alibali, M. (2014). Defining and measuring conceptual knowledge in mathematics. Developmental Review, 34(4), 344-377. https://doi.org/10.1016/j.dr.2014.10.001

Clarke-Midura, J. \& Dede, C. (2010). Assessment, technology, and change. Journal of Research on Technology in Education, 42(3), 309-328. https://doi.org/10.1080/15391523.2010.10782553

Canobi, K. (2009). Concept-procedure interactions in children's addition and subtraction. Journal of experimental child psychology, 102(2), 131-149. https://doi.org/10.1016/j.jecp.2008.07.008

Carr, M., Alexander, J. \& Folds-Bennett, T. (1994). Metacognition and mathematics strategy use. Applied Cognitive Psychology, 8(6), 583-595. https://doi.org/10.1002/acp.2350080605

Confrey, J. \& Lanier, P. (1980). Students' Mathematical Abilities: A Focus for the Improvement of Teaching General Mathematics. School Science and Mathematics, 80(7), 549-56. 
Carlson, P. (1998). A cross-sectional investigation of the development of the function concept, Research in collegiate mathematics education. III. CBMS issues in mathematics education, 114-162.

De Zeeuw, A., Craig, T. \& You, H. (2013). Assessing conceptual understanding in mathematics. In 2013 IEEE Frontiers in Education Conference (FIE) (1742-1744). IEEE.

Dixon, J. \& Moore, C. (1996). The developmental role of intuitive principles in choosing mathematical strategies. Developmental Psychology, 32(2), 241-253. https://doi.org/10.1037/0012-1649.32.2.241

Engelbrecht, J., Bergsten, C. \& Kågesten, O. (2017). Conceptual and procedural approaches to mathematics in the engineering curriculum: views of qualified engineers. European Journal of Engineering Education, 42(5), 570-586. https://doi.org/10.1080/03043797.2017.1343278

Eisenhart, M., Barko, H., Underhill, R., Brown, C., Jones, D. \& Agard, P. (1993). Conceptual knowledge falls through the cracks: Complexities of learning to teach mathematics for understanding. Journal for Research in Mathematics Education, 24(1), 8-40. https://doi.org/10.5951/jresematheduc.24.1.0008

Erlingsson, C. \& Brysiewicz, P. (2017). A hands-on guide to doing content analysis. African Journal of Emergency Medicine, 7(3), 93-99. https://doi.org/10.1016/j.afjem.2017.08.001

Frederick, F. \& Kirsch, L. (2011). Conceptual mathematics knowledge. In J. Collins III \& N. O'Brien (Eds.). The Greenwood Dictionary of education. $2^{\text {nd }}$ edn. Santa Barbara, CA: Greenwood, p.94

Faulkenberry, D. (2003). Secondary mathematics preservice teachers' conceptions of rational numbers. PhD. Dissertation, Oklahoma State University, Oklahoma.

Garofalo, J. \& Lester, F. (1985). Metacognition, cognitive monitoring, and mathematical performance. Journal for research in mathematics education, 16(3), 163-176. https://doi.org/10.5951/jresematheduc.16.3.0163

Hurrell, D. (2021). Conceptual knowledge or procedural knowledge or conceptual knowledge and procedural knowledge: Why the conjunction is important to teachers. Australian Journal of Teacher Education (Online), 46(2), 57-71.

Hussein, Y. \& Csaba C. (2021). How do secondary school students from the Kurdistan Region of Iraq understand the concept of function?. Teaching mathematics and computer science, 19/2, 221-244. https://doi.org/10.5485/TMCS.2021.0529

Hallett, D., Nunes, T., Bryant, P. \& Thorpe, C. (2012). Individual differences in conceptual and procedural fraction understanding: The role of abilities and school experience. Journal of Experimental Child Psychology,113(4), 469-486. https://doi.org/10.1016/j.jecp.2012.07.009

Hiebert, J. \& Carpenter, T. (1992). Learning and teaching with understanding. Handbook of research on mathematics teaching and learning: A project of the National Council of Teachers of Mathematics, 65-97.

Hiebert, J. \& Lefevre, P. (1986). Conceptual and procedural knowledge in mathematics: An introductory analysis. In J. Hiebert (Ed.). Conceptual and procedural knowledge: The case of mathematics, 2, 1-27. Hillsdale, NJ: Lawrence Erlbaum Associates.

Jacob, E. (1988). Clarifying qualitative research: A focus on traditions. Educational researcher, 17(1), 16-24. https://doi.org/10.3102/0013189X017001016

Khashan, K. (2014). Conceptual and procedural knowledge of rational numbers for Riyadh elementary school teachers. Journal of Education and Human Development, 3(4), 181-197. http://dx.doi.org/10.15640/jehd.v3n4a17

Korn, J. (2014). Teaching conceptual understanding of mathematics via a hands-on approach. Liberty University. 
Knuth, E., Alibali, M., McNeil, N., Weinberg, A. \& Stephens, A. (2005). Middle school students' understanding of core algebraic concepts: Equivalence \& variable. Zentralblatt für Didaktik der Mathematik, 37(1), 68-76. http://dx.doi.org/0.1007/BF02655899

Kilpatrick, J. (2001). The Standars of Mathematical Proficiency. Adding it up: Helping Children Learn Mathematics.

Long, C. (2005). Maths concepts in teaching: Procedural and conceptual knowledge. Pythagoras, (62), 59-65. http://dx.doi.org/10.4102/pythagoras.v0i62.115

Lampert, M. (2001). Teaching problems and the problems of teaching. Yale University Press. Linn, L. (1994). Performance assessment: Policy promises and technical measurement standards. Educational Researcher, 23(9), 4-14. http://dx.doi.org/10.3102/0013189X023009004

Lin, C., Becker, J., Byun, M., Yang, D. \& Huang, T. (2013). Preservice Teachers' Conceptual and Procedural Knowledge of Fraction Operations: A Comparative Study of the United States and Taiwan. School Science and Mathematics, 113(1), 41-51. http://dx.doi.org/10.1111/j.1949-8594.2012.00173.x

McLeod, D. (1992). Research on effect in mathematics education: A reconceptualization. Handbook of research on mathematics teaching and learning, 1, 575-596. http://dx.doi.org/10.1007/BF03217413

National Research Council, Mathematics Learning Study Committee, Kilpatrick, J.,

Swafford, J. \& Findell, B. (2001). Helping Children Learn Mathematics. Washington, DC: National Academy Press.

National Governors Association Center for Best Practices \& Council of Chief State School Officers. (2010). Common Core State Standards. National Governors Association Center for Best Practices, Council of Chief State School Officers, Washington D.C.

Nahdi, D. S., \& Jatisunda, M. G. (2020). Conceptual understanding and procedural knowledge: a case study on learning mathematics of fractional material in elementary school. Journal of Physics: Conference Series, 1477, (4), 042037. http://dx.doi.org/10.1088/1742-6596/1477/4/042037

National Council of Teachers of Mathematics (1989). Curriculum and evaluation standards for school mathematics. Reston, va: NCTM.

Nik Pa, N. A. (2003). Mathematics Education in Malaysia in the 21 st century. Hopes and challenges. Syarahan Perdana Universiti Malaya.

Putnam, R., Heaton, R., Prawat, R. \& Remillard, J. (1992). Teaching mathematics for understanding: Discussing case studies of four fifth-grade teachers. The Elementary School Journal, 93(2), 213-228. http://www.jstor.org/stable/1001702

Patton, M. (2001). Qualitative research and evaluation methods. $3^{\text {rd }}$ edn. USA: Sage Publications.

Rittle-Johnson, B. \& Schneider, M. (2015). Developing conceptual and procedural knowledge of mathematics. Oxford handbook of numerical cognition, 1118-1134. http://dx.doi.org/10.1037/0022-0663.93.2.346

Robson, C. (2011). Real World Research. John Wiley \& Sons Ltd: UK.

Robinson, K. \& Dube, A. (2009a). A Microgenetic study of the multiplication and division inversion concept. Canadian Journal of Experimental Psychology, 63(3), 193-200. http://dx.doi.org/10.1037/a0013908

Rittle-Johnson, B., Siegler, R. \& Alibali, W. (2001). Developing conceptual understanding and procedural skill in mathematics: An iterative process. Journal of educational psychology, 93(2), 346. http://dx.doi.org/10.1037/0022-0663.93.2.346

Rittle-Johnson, B. \& Alibali, M. (1999). Conceptual and procedural knowledge of mathematics: Does one lead to the other?. Journal of educational psychology, 91(1), 175-189. http://dx.doi.org/10.1037/0022-0663.91.1.175 
Rittle-Johnson, B. \& Siegler, R. (1998). The relation between conceptual and procedural knowledge in learning mathematics: A review In: Donlan, C. (Ed.) The development of mathematical skills. UK: Psychology Press/Taylor \& Francis, 75-110.

Reys, R., Suydam, M. \& Lindquist, M. (1995). Helping children learn mathematics. $4^{\text {th }}$ edn. Needham Heights, MA: Allyn and Bacon.

Schneider, M. \& Stern, E. (2010). The developmental relations between conceptual and procedural knowledge: A multimethod approach. Developmental psychology, 46(1), 178-192. http://dx.doi.org/10.1037/a0016701

Saha, R., Ayub, A. \& Tarmizi, R. (2010). The effects of GeoGebra on mathematics achievement: enlightening coordinate geometry learning. Procedia-Social and Behavioral Sciences, 8, pp. 686-693. http://dx.doi.org/10.1016/j.sbspro.2010.12.095

Star, J. (2005). Reconceptualizing procedural knowledge. Journal for research in mathematics education, 36(5), pp. 404-411. http://dx.doi.org/10.2307/30034943

Star, J. (2002). Re-Conceptualizing Procedural Knowledge: The Emergence of" Intelligent" Performances among Equation Solvers.

Tekin-Sitrava, R. (2017). Middle Grade Students' Concept Images of Algebraic Concepts. Journal of Education and Learning, 6(3), 299-304. http://dx.doi.org/10.5539/jel.v6n3p299

Wilson, L. (2016). Anderson and Krathwohl-Bloom's taxonomy revised. Understanding the New Version of Bloom's Taxonomy.

Walsh, M. (2001). Research Made Real: A Guide for Students. CHELTENHAM: Nelson Thornes Ltd.

Zuya, H. (2017). Prospective teachers' conceptual and procedural knowledge in mathematics: The case of algebra. American Journal of Educational Research, 5(3), 310-315. http://dx.doi.org/10.12691/education-5-3-12

Zaini, N. (2005). Conceptual knowledge in the topic of fractions among teachers training college. MA Dissertation. Universiti Kebangsaan Malaysia.

Zakaria, E., Yaakob, M., Maat, S. \& Adnan, M. (2010). Conceptual knowledge and mathematics achievement of matriculation students. Procedia-Social and Behavioral Sciences, 9, 1020-1024. http://dx.doi.org/10.1016/j.sbspro.2010.12.279

Zazkis, R. \& Hazzan, O. (1998). Interviewing in mathematics education research: Choosing the questions. The Journal of Mathematical Behavior, 17(4), 429-439. http://dx.doi.org/10.1016/S0732-3123(99)00006-1 